\title{
A cultura do não trabalho como um discurso vociferante, nas vozes de Brás Cubas e Quincas Borba
}

\author{
Angela Maria Rubel Fanini" \\ Gilberto Gnoato*" \\ Marcia dos Santos Lopes ${ }^{* * * *}$
}

\section{Resumo}

Este artigo analisa as construções discursivas sobre a cultura do trabalho na obra Memórias póstumas de Brás Cubas (1881), de Machado de Assis, fazendo um recorte discursivo das vozes representadas pelos personagens Brás Cubas e Quincas Borba. Considerando que o universo cultural criado pelo autor romanesco reflete e refrata o seu tempo e que não há como afastar a cultura da orientação dialógica da linguagem, já que estas pressupõem alteridade e discursividade, fazemos uma análise dialógica do discurso, baseada nas teorias de Bakhtin e do Círculo. As vozes da enunciação machadiana contrapõem o discurso de longa duração da dignidade, do reconhecimento e da realização pessoal, advindo do trabalho material ou imaterial, ao discurso do não trabalho ou antitrabalho das classes dominantes, que têm "sede de nomeada”, pela aquisição de um diploma ou por um cargo político. Concluiu-se que, para as elites brasileiras oitocentistas, o que prevalecia era a cultura do não trabalho.

Palavras-chave: Cultura. Trabalho. Discurso. Cubas e Borba. Machado de Assis.

\footnotetext{
Professora Doutora do Programa de Pós-Graduação em Tecnologia e Sociedade (PPGTE) da Universidade Tecnológica Federal do Paraná (UTFPR). Bolsista de Produtividade em Pesquisa CNPq. E-mail: rubel@ utfpr.edu.br

** Doutorando do Programa de Pós-Graduação em Tecnologia e Sociedade (PPGTE) da Universidade Tecnológica Federal do Paraná (UTFPR). E-mail: ggnoato@ gmail.com

**** Doutoranda do Programa de Pós-Graduação em Tecnologia e Sociedade (PPGTE) da Universidade Tecnológica Federal do Paraná (UTFPR). E-mail: marcialopes@ utfpr.edu.br
} 


\section{Introdução}

No ato social de trabalhar, o homem relaciona-se com o outro, convive e estabelece relações de alteridade, além de garantir sua sobrevivência e a de sua família com o assalariamento. De posse da palavra, contudo, não apenas trabalha como também fala e escreve sobre seu trabalho, proferindo vozes sobre o seu labor diário, que têm como referente sua lida presente, mas também nos vêm de longa data, visto que o trabalho sempre foi objeto discursivo das enunciações cotidianas, das obras jurídicas, filosóficas e de guias morais criadas pelos homens. Muitas delas chegam até o nosso tempo por intermédio da arte literária, que recupera vozes não só de seu tempo, mas de uma temporalidade passada, em uma dialogia ininterrupta que traz novamente e em nova chave vozes de outros cronotopos.

Machado de Assis, em suas obras escritas no século XIX, apresenta diversas vozes em diálogo com seu tempo, com o passado e ecoando no futuro, do qual fazemos parte. Este artigo analisa, especificamente, as construções discursivas sobre o trabalho como atividade humana, assalariada ou não, na obra Memórias póstumas de Brás Cubas, doravante Memórias póstumas, escrita por Machado de Assis, doravante Machado, sob a perspectiva de Bakhtin e do Círculo.

São trazidas para a análise vozes que, aparentemente, não representam a cultura oficial e hegemônica do trabalho, preconizada, sobretudo, pelas classes mais abastadas, no tempo de Machado, em que se propala o labor como fonte de dignidade, de reconhecimento e realização pessoal e como essencial na constituição da identidade do ser social. Os discursos que enobrecem o trabalho parecem estar ausentes da obra. As vozes dos personagens Brás Cubas e Quincas Borba são o objeto desta análise, pois representam a cultura do não trabalho ou antitrabalho. Essas vozes indicam certa "sede de nomeada", ${ }^{1}$ ou seja, uma busca de nomeação e de glória, alcançada pela aquisição de um diploma e por meio de cargos públicos, atividades imateriais significativas para aqueles que não precisam trabalhar arduamente para sobreviver.

Nessa perspectiva, intenta-se fazer uma análise dialógica do discurso (ADD), ${ }^{2}$ de cunho bakhtiniano, para a qual a palavra, inclusive a literária, carrega consigo sempre o peso da cultura, concebida como um "código", um "receituário", um "mapa" de orientação para a vida social (DAMATTA, 1986, p. 123), como uma ciência interpretativa em busca de significados (GEERZ, 2014, p. 15) ou como uma teia de significados tecida pelo homem e na qual ele se encontra amarrado, segundo Max Weber (apud GEERZ, 2014, p. 15).

$\mathrm{O}$ universo cultural reflete e refrata 0 tempo em que se vive, a economia em que se trabalha, as igualdades e desigualdades sociais e os sonhos e as angústias dos homens. Entretanto, a enunciação 
literária não é só uma resposta ao seu tempo, mas, como já referido, responde a uma temporalidade maior, da qual o presente faz parte, recuperando as palavras de outros contextos temporais e espaciais. Busca-se também reconhecer os discursos já consagrados culturalmente sobre o trabalho e que impõem a manutenção de certa ordem discursiva como um traço cultural e de identidade do povo brasileiro, considerando que, segundo Bakhtin, quando entramos em contato com um objeto, seja ele qual for, já o encontramos discursado:

Todo discurso concreto (enunciação) encontra aquele objeto para o qual está voltado sempre, por assim dizer, já desacreditado, contestado, avaliado, envolvido por sua névoa escura ou, pelo contrário, iluminado pelos discursos de outrem que já falaram sobre ele. O objeto está amarrado e penetrado por ideias gerais, por pontos de vista, por apreciações de outros e por entonações. Orientado para o seu objeto, o discurso penetra neste meio dialogicamente perturbado e tenso de discursos de outrem, de julgamentos e de entonações (BAKHTIN, 2010, p. 86).

O romance de Machado, como qualquer outro texto literário canônico, é um discurso em movimento, formado por um circuito de vozes e, embora já o encontremos lido e analisado, não se esgota. Quando Machado escreve sobre o trabalho dos seus personagens, já encontra a ideia de cultura do trabalho discursada. Porém, sua escrita personaliza esse objeto, na sua perspectiva pessoal de autor, reagindo globalmente ao ato social de trabalhar sem, no entanto, buscar determinações estáveis para esse ato (BAKHTIN, 2000, p. 27). Do mesmo modo, reduz estruturalmente a realidade externa, transformando-a em dados internos à obra (CANDIDO, 2006). A obra volta-se para seu tempo, mas não o reproduz, antes o recria mediante uma visão peculiar, embora compartilhada, ou seja, há uma voz autoral e um estilo pessoal, mas que também se insere em uma tradição discursiva literária. Essa pessoalidade da obra deve ser buscada na leitura de sua escrita como um todo, para, então, captar regularidades temáticas e expedientes formais que comporão a análise dialógica do discurso. Para este artigo, devido ao formato, delimitou-se apenas um romance, recortando a temática do trabalho e analisando dois personagens sobre essa questão.

Como analistas do discurso, procurou-se revelar a particularidade social do texto literário, penetrando na tensão que ele provoca e que se estabelece ao analisar o discurso em interação com a realidade social e cultural brasileira do século XIX. No entanto, não se desvinculou essa análise do viés axiológico a que o texto está ligado moralmente e nem se pretendeu analisar o conteúdo da obra, mas os caminhos que conduzem à produção do discurso da cultura do trabalho negada pelo não trabalho. 
Discursos sobre

o trabalho: a

imaterialidade como

forma de manutenção

dos privilégios de uma

classe social

Ao longo da história, o trabalho material vem sendo discursado de diversas formas. Nos escritos da cultura grega antiga, havia já posições díspares, pois muitos o desprezavam, atribuindo-o ao escravo, enquanto outros o dignificavam, como Hesíodo (1996) ${ }^{3}$ e Ésquilo (1980). ${ }^{4}$ Assim também ocorre com os vários livros que compõem a Bíblia, em que se o preconiza o trabalho como um castigo ao homem pela sua desobediência às ordens divinas, mas também se o percebe como bem coletivo e necessário. ${ }^{5}$ Citamos esse conjunto discursivo uma vez que ainda circulava na época de Machado, apresentando poder heurístico sobre o objeto em questão.

Nesse percurso, o trabalho humano já adquiriu muitos outros sentidos, positivados ou negados: a única forma de sobrevivência; uma obrigação para ocupar o corpo e a mente; uma atividade derrogatória; um castigo; o formador da dignidade humana; o condutor do reconhecimento; o produtor da realização; o constituidor da identidade; até mesmo o de ser negado pelas elites.

Da mesma forma, historicamente, estabeleceu-se a diferença crucial entre trabalho material e trabalho imaterial.
Pelo material, tem-se a construção de muito do que existe a nossa volta. Pelo imaterial, tem-se a projeção de muito do que foi arquitetadamente criado ao nosso redor. Em outras palavras, ambos têm sua importância crucial para a humanidade. No entanto, social e historicamente, o trabalho imaterial, não físico e apenas mental, ao longo dos séculos, tem ganhado projeção e assumido um papel de liderança em uma ordem de prestígios e privilégios sociais. Por essa razão é o tipo de atividade mais desejada, como um fetiche para as classes menos prestigiadas. Já a atividade material é considerada vergonhosa, aviltante, para os que dela dependem, ainda que haja um discurso contrário, de que nenhum trabalho é desonroso. Logicamente, esta divisão já é axiológica, pois não existe trabalho material sem um pensamento que o conduza, oriente, imprima-lhe um telos. Talvez só o trabalho completamente mecânico, se é que existe, prescinde de um pensamento que o acompanhe. Essa dicotomia sempre dividiu a sociedade, originando discursos desabonadores para o trabalho material e dignificadores para o imaterial, mas ela é fruto de uma sociedade dividida em classes sociais que se beneficiam da materialidade do trabalho de outrem. No romance que analisamos, vemos personagens oriundos das classes abastadas reforçando essa posição.

Quanto à realidade brasileira, o historiador Sérgio Buarque de Holanda, em seu livro Raízes do Brasil, afirma que, 
dentre tantas características do povo ibérico, e por suposto o brasileiro, que ele julga presentes no caráter do homem colonizado, está a "invencível repulsa que sempre lhes inspirou toda moral fundada no culto ao trabalho", por isso nunca se naturalizou entre os ibéricos "a moderna religião do trabalho e o apreço à atividade utilitária". Complementando esse raciocínio, o autor afirma que:

Uma digna ociosidade sempre pareceu mais excelente, e até mais nobilitante, a um bom português, ou a um espanhol, do que a luta insana pelo pão de cada dia. O que ambos admiram como ideal é uma vida de grande senhor, exclusiva de qualquer esforço, de qualquer preocupação. E assim, enquanto povos protestantes preconizam e exaltam o esforço manual, as nações ibéricas colocam-se ainda largamente no ponto de vista da Antiguidade clássica. O que entre elas predomina é a concepção antiga de que o ócio importa mais que o negócio e de que a atividade produtora é, em si, menos valiosa que a contemplação e o amor (HOLANDA, 2009, p. 38).

A moral do trabalho para espanhóis e portugueses representava um "fruto exótico". Holanda aponta, ainda, características peculiares aos portugueses, como a obediência, mesmo sendo rara e difícil, vista como um bem supremo, entre povos nos quais a vontade de mandar e a disposição para se cumprir ordens eram igualmente peculiares; e a falta de energia para arregaçar as mãos e trabalhar.

Segundo Holanda, os portugueses, no Brasil, buscavam glória e riqueza, sem trabalho e sem sacrifício, por meio das mãos e dos pés dos negros: "riqueza que custa ousadia, não riqueza que custa trabalho" (HOLANDA, 2009, p. 49). E alcançaram esse objetivo facilmente com os africanos trazidos por meio do comércio negreiro.

No Brasil, a organização dos ofícios segundo moldes trazidos do reino teve seus efeitos perturbados pelas condições dominantes: preponderância absorvente do trabalho escravo, indústria caseira capaz de garantir relativa independência aos ricos, entravando, por outro lado, o comércio, e, finalmente, escassez de artífices livres na maior parte das vilas e cidades (HOLANDA, 2009, p. 57-58).

Nessa realidade e nessas condições, o trabalho real era o material, praticado pelo escravo, e algumas outras tarefas, que garantiam a sobrevivência de homens e mulheres, livres, brancos ou negros. No topo da pirâmide estava uma pequena elite branca, constituída dos senhores detentores dos bens de produção e de alguns improdutivos, que viviam de herança e de gastar o dinheiro da família.

Para o antropólogo DaMatta, o trabalho no sistema brasileiro é concebido como castigo:

[...] e o nome diz tudo, pois a palavra deriva do latim tripaliari, que significa castigar com o tripaliu, instrumento que, na Roma Antiga, era objeto de tortura, constituindo uma espécie de canga usada para supliciar escravos. [...] Muito diferente da concepção anglo-saxã que equaciona trabalho (work) com agir e fazer, de acordo com a sua concepção original. Entre nós, porém, perdura a tradição católica romana e não a tradição calvinista, achamos que o trabalho é um horror (DAMATTA, 1993, p. 31). 
Não foram apenas os ofícios que foram organizados à maneira do reino, conforme afirma Sérgio Buarque de Holanda, mas a própria sociedade vivia uma realidade fora de lugar, deslocada, como diria Roberto Schwarz, tendo como resultado da colonização com base no monopólio da terra a produção de três classes sociais: o latifundiário, o escravo e o "homem livre", na verdade dependente (SCHWARZ, 2012, p. 1516). As três classes estão indiretamente representadas em Memórias póstumas: o escravo, o agregado ou o homem livre e pobre e a elite dominante, sobre a qual nos debruçamos neste artigo e que, embora não seja latifundiária, detém $o$ poder econômico.

Uma lente capaz de aproximar-nos da realidade do contexto de Brás Cubas e Quincas Borba é o discurso do trabalho elaborado por Paul Lafargue. ${ }^{6} \mathrm{Na}$ contramão do Capitalismo e das ideias marxianas, referindo-se ao apego da sociedade proletária do século XIX ao trabalho, Lafargue afirma que o amor ao trabalho é uma "estranha loucura" e que apenas existe para aqueles que não fazem parte da classe burguesa. Para os que não precisam trabalhar para se sustentar, essa loucura não existe. "O fantasma que ronda a sociedade" é a forma encontrada pelas classes sociais mais altas para impor um dever aos de classe inferior, no caso escravos, ex-escravos e agregados, e projetar-se a si mesmos socialmente (LAFARGUE, 1977, p. 15).

Nesse contexto, a ideia de dignidade, reconhecimento e realização pessoal associada a trabalho é um mito do liberalismo, implantado deslocadamente no país, onde quem realmente trabalhava era o escravo e as elites viviam em busca de glória, sem esforço ou labor.

A visão negativa sobre o trabalho material vincula-se no Brasil oitocentista diretamente ao estatuto da cultura escravocrata e ao escravismo econômico, pois, como já mencionado, o trabalho era atividade de escravos, portanto, para se diferenciar deles, era necessário não trabalhar. Assim, tanto a elite o vê como derrogatório quanto os pobres livres o afastam de si, procurando o clientelismo e o apadrinhamento, no sentido de se diferenciarem dos escravos, adquirindo uma identidade de homens livres, não cativos.

\section{Procedimentos metodológicos}

Este artigo resulta dos incessantes questionamentos e discussões sobre os discursos do trabalho, realizados pelo grupo de pesquisa Discurso sobre Tecnologia, Trabalho e Identidades Nacionais, do Programa de Pós-Graduação em Tecnologia e Sociedade (PPGTE) da Universidade Tecnológica Federal do Paraná (UTFPR).

Como parte de projeto de pesquisa maior, intitulado A formalização discursiva do universo do trabalho e da tecnologia em textos literários, do CNPq, buscou-se pesquisar obras literárias brasileiras, canônicas ou não, com o intuito 
de alcançar os discursos sobre o trabalho presentes nas escolhas dos autores. No caso da pesquisa aqui empreendida, optou-se por Memórias póstumas, dentre tantas obras de Machado, como um recorte possível, compreendendo que a obra machadiana compõe um enunciado maior, o qual só pode ser alcançado em pequenas porções.

A investigação cumpriu o percurso a seguir: inicialmente, leu-se a obra, buscando coletar dados e encontrar personagens principais, secundários ou simplesmente citados no texto e suas atividades que determinassem um ou alguns discursos sobre o trabalho. Nesse sentido, percebeu-se que seriam muitos caminhos e que levariam a uma vastidão de dados. Configurou-se um quadro, no qual apareceram escravos e escravas, cortesãs, almocreves, alcoviteiras, capitães-mores, oficiais de infantaria, lavradores, tanoeiros, inspetores de quarteirão, dentre outras atividades, além de licenciados, filósofos, cônegos, deputados, ministros, etc. Entretanto, algumas dessas profissões, ofícios ou atividades, apesar de representarem trabalho, assalariado ou não, e contribuírem para a formação de um discurso sobre o trabalho, não eram suficientes para a análise dos discursos sobre o trabalho na sociedade brasileira, porque surgiam brevemente como um cenário de composição de uma peça teatral e da mesma forma desapareciam.

Assim, afunilando um pouco mais o olhar, percebeu-se a força da presença da agregada alcoviteira, do menino e homem escravizado e dos dois homens ricos, entre eles o personagem principal e narrador da obra, representantes da elite improdutiva, e suas atividades no campo da ciência e da filosofia. Os quatro personagens traziam à tona o panorama das classes sociais existentes e predominantes no século XIX, no Brasil, de forma escancarada. Dessa maneira e com esses personagens, constituiu-se uma engrenagem a partir da qual era possível ler os discursos sobre o trabalho como atividade humana em diálogo com discursos já existentes e predominantes na sociedade sobre o trabalho ontológico.

$\mathrm{O}$ recorte escolhido para este artigo consiste nos personagens que representam homens ricos na sociedade oitocentista. Brás Cubas e Quincas Borba foram escolhidos, por representarem uma das três pontas de uma pirâmide constituidora da sociedade brasileira do século XIX.

Assim, depois de alguns percalços, chegou-se ao discurso do não trabalho ou do antitrabalho, no qual se tem especial interesse neste artigo. A escolha da nomenclatura "não trabalho" ou "antitrabalho" para o discurso de Brás Cubas e Quincas Borba resulta da posição axiológica em que emerge o trabalho material como negativo, reforçando a visão derrogatória do labor material em decorrência da escravidão brasileira oitocentista. Esses personagens, embora particularizados na obra, remetem a uma posição de classe vinculada às elites improdutivas, para quem o trabalho 
constante, material, produtor de bens de consumo ou duráveis, não era obrigação das castas abastadas. Obviamente que não representam toda a elite da época, classe em que havia indivíduos que trabalhavam no sentido de construir a nação, desenvolver a economia, promover o comércio, a educação, a tecnologia e a indústria. O Brasil constitui-se enquanto nação somente no século XIX, e muitos dirigentes contribuíram para a sua consolidação econômica, tecnológica e cultural.

Nossos personagens, no entanto, na visão de Machado, não pertencem a essa parte da elite, e sim a uma elite improdutiva acostumada a viver do trabalho alheio, buscando tão somente a glória, o ócio, o hedonismo e o consumo de toda sorte de bens materiais e imateriais. É uma elite não burguesa no sentido clássico, pois não é industriosa como foi a da Europa, mormente a inglesa que revolucionou os meios de produção com a Revolução Industrial e os meios culturais e educacionais, constituindo um saber científico pragmático, que pudesse gerar maquinaria, ou seja, tecnologia.

Essas falas foram vistas indicando sua referência à economia e às culturas oitocentistas brasileiras, mas também se pensando o Brasil como integrante da economia europeia. A dimensão infraestrutural econômica age nos discursos proferidos, e esses também interagem naquela, reforçando-a, carnavalizando-a ou desestabilizando-a, conforme Bakhtin (2000). Também se procurou investigar a forma como discursos milenares de nossa cultura transitam nas falas dos personagens e aí sofrem deslocamentos em decorrência de sua nova posição econômica e cultural, entendendo os discursos em sua dialogia com outros cronotopos.

Quanto ao corpus de análise, é possível perceber uma maior apreciação dos elementos do discurso a partir do personagem Brás Cubas, que é o narrador e personagem principal da obra, cabendo a ele apontar os caminhos para que o leitor se aproxime e alcance a sua narrativa. Quanto a Quincas Borba, por ser um personagem secundário e já bastante presente na obra homônima, o corpus coletado para análise é menor e por isso poucas páginas são dedicadas a ele neste artigo, mas isso não diminui seu valor e sua importância no que diz respeito ao aprofundamento da análise da questão do não trabalho ou do antitrabalho na obra de Machado de Assis.

\section{Trabalho e antitrabalho na voz de Brás Cubas}

A característica portuguesa relacionada ao gosto pela vida de grande senhor e repulsa ao trabalho, demonstrada pelo historiador Sérgio Buarque de Holanda, tem seus matizes em vários momentos da narrativa machadiana. Em Memórias póstumas, tudo começa pela confissão do defunto-autor, Brás Cubas, de que a ideia do emplasto, que o levou à morte, influenciou-o, principalmente, pelo gosto de ver impressas nos jornais, mostrado- 
res, folhetos, esquinas e, enfim, nas caixinhas do remédio, estas três palavras: "Emplasto Brás Cubas" (MACHADO, 1997, p. 15). Em outras palavras: Cubas queria ser ovacionado, tinha amor pela fama e pela glória. A essa busca chamá-la-emos, como Machado a chamou, de "a outra flor menos amarela e nada mórbida - o amor da nomeada". Era a ideia "trapézio" que o perseguira durante algum tempo. E continuando:

Para que negá-lo? Eu tinha a paixão do arruído, do cartaz, do foguete de lágrimas. Talvez os modestos me arguam esse defeito; fio, porém, que esse talento me hão de reconhecer os hábeis. Assim, a minha ideia trazia duas faces, como as medalhas, uma virada para o público, outra para mim. De um lado, filantropia e lucro; de outro, sede de nomeada. Digamos: - amor da glória (ASSIS, 1997, p. 15).

Assim, vê-se claramente que não se está a constituir uma visão de trabalho que dignifica o caráter, constrói um bem comum, identifica o produtor como um cientista em prol de melhorias sociais. Antes, o que o move é a vaidade, o orgulho, o individualismo, o narcisismo. Ainda na tentativa de apresentar esse sentimento relacionado ao arruído e ao cartaz, o narrador cita dois tios seus que têm pensamentos opostos sobre o tema. O tio cônego, portanto religioso, dizia que "o amor da glória temporal era a perdição das almas, que só devem cobiçar a glória eterna". Outro tio, militar, afirmava que "o amor da glória era a coisa mais verdadeiramente humana que há no homem, e, conseguintemente, a sua mais genuína feição" (ASSIS, 1997, p. 15).
Duas vozes de longa duração cruzam-se na voz de Brás Cubas: a primeira, de origem religiosa, muito repercutida durante os séculos em que a Igreja Católica implantou o Cristianismo na colônia, representa um discurso desviante da ideia de acúmulo, própria do pensamento capitalista, ou seja, reforça o pensamento de que se deve cobiçar e ansiar por coisas espirituais e não pelos bens materiais; a segunda voz, dita por um militar, é um discurso do terreno e humano, estimula a busca da honra sobre todas as coisas, justificando essa necessidade na própria essência do homem, que é o autoenaltecimento. Também aí, vê-se a recuperação não direta, mas indireta, de outro discurso de longa duração. Em Eclesiastes, bastante lido em nossa cultura ocidental, profere-se que o trabalho nada mais é que vaidade humana. ${ }^{7}$

Nessa perspectiva, não é o trabalho que é central e essencial na vida do homem, pelo menos na vida das elites. $\mathrm{O}$ que é central na vida dessa classe social é o arruído, sem esforço; é o cartaz e a ostentação, chamando a atenção de todos para si. Holanda atribui esse caráter ao povo ibérico, e Machado coloca-o como um traço distintivo da sociedade da qual Brás Cubas fazia parte, ou seja, uma sociedade de classes e escravista, para quem o trabalho produtivo material é exclusivo de escravos e não glorifica o homem. Ressaltamos que a elite aqui é representada em seu pior viés, sendo improdutiva e superficial. O texto literário não abarca toda a elite oitocentista, mas uma parte 
que é dada pelo viés machadiano, cuja visão crítica decide destacá-la.

No capítulo III de Memórias póstumas, intitulado Genealogia, temos outra demonstração do que vem a ser o amor à glória, quando Brás Cubas narra a razão do seu sobrenome. Cubas traça um perfil de sua família como uma possível representação da sociedade brasileira, formada nos últimos séculos, e da cultura brasileira que aparentemente venera o trabalho. O personagem-narrador explica ao leitor, de forma bastante irônica, como é própria a Machado, sua genealogia, a partir do nome familiar, Cubas. Conta que o fundador de sua família era um tanoeiro 8 de ofício, "e talvez mau tanoeiro", Damião Cubas, natural do Rio de Janeiro, ou seja, um profissional do meio urbano, que teria morrido na penúria e na obscuridade, se apenas exercesse a tanoaria. Como buscou outras fontes de renda, tornando-se lavrador, plantando, colhendo e permutando seu produto por bom valor, morreu rico, deixando herança a seu filho Luís Cubas, um jovem licenciado ${ }^{9}$ em Coimbra. É a partir do nome desse moço que começa a família confessa do narrador-defunto, pois sua "verdadeira" família sempre negou a existência do nome Damião Cubas, reconhecendo apenas o filho, Luís Cubas, como ancestral legítimo, por esse ter sido primado no Estado e amigo particular do vice-rei, conde da Cunha (MACHADO, 1997, p. 16).

O que se tem nessa configuração é, sobretudo, a valorização que o trabalho imaterial traz em detrimento da desvalorização social do trabalho material. A tanoaria, por exemplo, era um trabalho de grande importância, uma arte, mas como estava associada aos escravos, categoria sem prestígio social, e ao trabalho material, braçal, físico, não trazia nenhum valor social. Ser tanoeiro já tinha sido motivo de orgulho no passado, mas, naquela sociedade ou para a família de Cubas, constituía-se como uma vergonha, um signo de pobreza, pois lidava com excrementos, e o indivíduo que lida com algo vinculado a isso é dado como um sujeito que não merece valor social.

Por isso, o antepassado de Cubas tornou-se lavrador. No entanto, ele não era alguém que trabalhava na terra de um latifundiário, por exemplo, era um proprietário, que lavrava sua própria terra e, por isso, sua escolha pela lavoura em detrimento da tanoaria tinha uma razão de ser. A profissão de lavrador tem um valor axiológico relacionado à terra $\mathrm{e}$ a tudo o que diz respeito a ela, inclusive a sua posse, sua propriedade. Um lavrador dono de sua própria terra vive no meio rural e é símbolo de simplicidade, pureza e dignidade, visto como constituído de valores nobres e reconhecido por isso, porque lida com a terra, que é um signo milenar. Quem possui a terra ou um quinhão próprio para morar está em vantagem em relação aos que não a possuem. Mesmo assim, lavrar a terra é um trabalho material, ainda que já indique melhor prestígio do que a tanoaria.

Quando a família Cubas prefere ser reconhecida pelo antepassado que era 
licenciado e não pelo tanoeiro ou lavrador, ofícios bastante comuns à época, Machado apresenta uma voz reforçando o discurso de que, naquela sociedade, $o$ trabalho imaterial prevalecia sobre o trabalho material, braçal, que traz dores físicas. O melhor, naquela época como hoje, era ilustrar-se para ser valorizado. Ser licenciado não era necessariamente um trabalho, no real sentido do verbo trabalhar, mas significava intelectualidade, saber lidar com o conhecimento, com as palavras e não fazer esforço físico, pois geralmente estaria sempre sentado e escrevendo. Isso satisfazia a "sede de nomeada” do personagem Brás Cubas, bacharel em Direito, que não exercia a profissão. Da mesma forma, ser um capitão-mor indicava uma posição privilegiada de poder sobre outras patentes, bem como ser secretário, deputado ou ministro, que eram os desejos de Brás Cubas, ao longo da sua narrativa.

Cada um dos antepassados do defunto-autor, narrados no capítulo em questão, tinha uma profissão, um ofício e, independente disso, era marcado socialmente pelo trabalho. Dessa perspectiva, o trabalho parece humanizar o homem, afastando-o da animalidade e dando-lhe um lugar na sociedade. $\mathrm{O}$ discurso que prevalece é o de que, pelo trabalho, o homem torna-se alguém, faz-se conhecido e se conhece. Mesmo assim, o discurso do trabalho está em embate com outra enunciação, que diz que nem todo labor gera o reconhecimento desejado, ou seja, trabalho bom é aquele que não se precisa fazer força, carregar peso, gastar as ener- gias, e essas atividades são reservadas às elites dominantes. Isso mostra como o texto romanesco, ao mesmo tempo em que reflete a realidade social, cronotópica, refrata-a, apresentando-a também a partir de um olhar de classe.

No exemplo do capítulo em questão, temos uma enunciação que vem de discursos antigos e já tem uma resposta no futuro anunciado. "É a língua do dia, da época, duas tendências opostas da vida verbal, formadas no plurilinguismo dialogizado, anônimo e social como linguagem, mas concreto, saturado de conteúdo e acentuado como enunciação individual" (BAKHTIN, 2010, p. 82). As vozes que gritam, entre tantas outras, são a do embate entre o orgulho e o preconceito, gerado pela condenação social diante de determinadas tarefas socialmente não aceitas, como a do tanoeiro, e a que coloca o não trabalho ou o antitrabalho como simbólico de uma classe social privilegiada. Independente de qual embate determina a maioria das relações, a cultura do trabalho como um discurso vigente prevalece, sendo sobretudo negada. O trabalho aparece pelo que não é. Rejeita-se o trabalho material e, nessa rejeição, identifica-se a classe de quem a profere.

Para Cubas, não é suficiente dizer quem ele é no momento presente, porque sua subjetividade está marcada pelo repertório familiar, pelas condutas que antecederam a sua vida na terra. Basta observar a fala final do personagem-narrador, irônico e satírico, no último capítulo Das Negativas: 
Este último capítulo é todo de negativas. Não alcancei a celebridade do emplasto, não fui ministro, não fui califa, não conheci o casamento. Verdade é que, ao lado dessas faltas, coube-me a boa fortuna de não comprar o pão com o suor do meu rosto. Mais; não padeci a morte de Dona Plácida, nem a semidemência do Quincas Borba. Somadas umas coisas e outras, qualquer pessoa imaginará que não houve míngua nem sobra, e conseguintemente que saí quite com a vida. E imaginará mal; porque ao chegar a este outro lado do mistério, achei-me com um pequeno saldo, que é a derradeira negativa deste capítulo de negativas: - Não tive filhos, não transmiti a nenhuma criatura o legado da nossa miséria (ASSIS, 1997, p. 220).

Nessa fala, emerge o discurso bíblico em que o trabalho é fardo (suor), entretanto, aqui se desafia esse discurso, pois o personagem não foi atingido pela maldição. Paira acima do mal, sendo elite. Carnavaliza-se o discurso bíblico ao confrontá-lo com o chão histórico das classes abastadas, e ele se neutraliza, pois não as atinge. A enunciação de longa duração é mobilizada para ser enfraquecida e demonstrar que, em uma sociedade de classes, o discurso não reveste toda a realidade, mas se origina de mirantes ideológicos díspares. Nesse sentido, até mesmo para estabelecer sua crítica a essa forma de encarar a representatividade social e sua importância, Machado usa a palavra para tridimensionar a genealogia de Cubas, apresentando quem eram realmente seus antepassados, quem eles queriam ser e por quem os parentes mais próximos a ele queriam ser conhecidos no momento presente à narrativa. Ironicamente, Brás Cubas não se inclui no grupo dos antepassados da família Cubas, quando deveria, pois é um autor-defunto e está contando a história do seu passado, no qual também está incluído, obviamente. Ele não se inclui, porque não se julga merecedor: seu histórico não é dos melhores para ser incluído nessa genealogia, já que, quando vivo, era um homem rico, um bon vivant, que nunca trabalhou, alimentado pelas relações de poder de seu pai, ainda que se considere isento de qualquer julgamento humano, por estar contando a sua história a partir de outra dimensão, longe do olhar da opinião que tanto molesta o homem, socialmente. Talvez, ao não se incluir, esteja incluindo-se.

Como vemos, Brás Cubas é o defunto-autor, traduzindo o ponto de vista axiológico de Machado ${ }^{10}$ sobre as relações sociais, o trabalho e as mudanças sociais pelas quais passava sua época. Esse é um expediente formal utilizado pelo autor para dar-se a possibilidade de autoironia. Brás Cubas tem um excedente de visão, ${ }^{11}$ que enxerga o outro de fora, mas que está dentro do social, pois escreve para o outro ler, dando-lhe a oportunidade de criticar a si e ao outro. Dessa forma, traz para a realidade textual as formas de trabalho que existiam no século XIX, que eram discursivamente propagadas ou apagadas por um discurso mais forte e mais duradouro. $\mathrm{O}$ defunto-autor, segundo ele mesmo, pode já ver com mais argúcia e verticalidade a realidade, já não precisa ter cuidado em não proferir a verdade, pois está acima do bem e do mal, não pode ser julgado 
pelos pares, uma vez que se encontra em outro cronotopo. Essa exotopia o permite ser crítico e satírico com o mundo do trabalho, revelando falas que o desmerecem e o desabonam.

No mundo em que as relações de poder instituídas impõem-se, valoriza-se quem o detém, hierarquizando-as. $\mathrm{O}$ trabalho é um dos fatores de identidade social, que vem carregado de significados e de poder. Segundo a visão marxiana, por meio do trabalho também se estabelecem as diferenças sociais (MARX; ENGELS, 1997). Assim, seria redundante afirmar que certos trabalhos são considerados inferiores, como a atividade material da tanoaria ou da lavoura, em detrimento de outros que pressupõem respeito, como as atividades imateriais do licenciado, capitão-mor ou deputado.

Segundo Holanda (2009, p. 58), a lei do século XIX não estabelecia hierarquia entre os ofícios manuais, mas havia discriminações já consagradas pelos costumes e uma intolerância maior em relação aos ofícios de mais baixa reputação social. A tanoaria era um desses ofícios, hierárquica e culturalmente, reprovados e desqualificados socialmente. De outro modo, as atividades imateriais, como as praticadas pelos personagens Luis Cubas, licenciado, Brás Cubas, diplomado em Lisboa e deputado, e Quincas Borba, com sua filosofia do Humanitismo, eram respeitadas hierarquicamente. Brás Cubas e Quincas Borba, personagens que nos interessam nesta análise, escreviam sobre filosofia, política ou literatura:

Mandava artigos e versos para as folhas públicas e cheguei a alcançar certa reputação de polemista e de poeta. Quando me lembrava do Lobo Neves, que era já deputado, e de Virgília, futura marquesa, perguntava a mim mesmo por que não seria melhor deputado e melhor marquês do que o Lobo Neves, - eu, que valia mais, muito mais do que ele, - dizia isto a olhar para a ponta do nariz [...] (ASSIS, 1997, p. 93).

Porém, a carreira de escritor era pouco para o objetivo de Cubas, que queria ser ufanado, glorificado, em conformidade com a cultura na qual estava inserido, já que o trabalho imaterial, como valor, conforme mencionado, é também um traço cultural brasileiro e uma atitude consagrada nos meios sociais e no cotidiano, em que a maioria era escrava ou ex-escrava e vivia de trabalhos pesados, que dependiam de força física. Nisso se mantém a ordem discursiva, que põe em uma balança o trabalho imaterial, ilustrado, praticado por homens livres e ricos, que nem precisam dele, em contraposição ao trabalho material, feito com esforço físico sobre-humano, nas formas, sobretudo, do escravismo.

O narrador-defunto deixa antever que eram construídos muitos castelos em torno do ideal da glória e de um passado luminoso, pela conquista de um lugar nobre, um cargo político ou uma posição de poder. Essas posições demarcavam fronteiras sociais e econômicas e envolviam o homem em uma atmosfera de orgulho ou vergonha social, a partir do seu exercício, e por isso eram objeto de 
desejo das classes privilegiadas da época, que as mantinham a todo custo, porque não desejavam perder seu prestígio.

Eram tantos os castelos que engenhara, tantos e tantíssimos os sonhos, que não podia vê-los assim esboroados, sem padecer um forte abalo no organismo. [...] Um Cubas! E dizia isso com tal convicção, que eu, já informado da nossa tanoaria, esqueci um instante a volúvel dama [...] (ASSIS, 1997, p. 88).

Da construção desses castelos e de um futuro promissor fazia parte a entrada do jovem do século XIX na universidade. Era preciso construir uma história para o passado desses portugueses que aqui moravam, como vimos no capítulo Genealogia. O Brasil ainda era muito primitivo em relação aos países da Europa e tinha inúmeras deficiências aos padrões da elite. Como se sabe, por exemplo, diferentemente das colônias inglesas e espanholas, o Brasil como colônia de Portugal só veio a fundar suas primeiras instituições culturais e científicas no século XIX, especificamente em 1808, quando a família real chegou ao Brasil. Até então, os jovens como Cubas eram conduzidos à Europa para completar seus estudos e voltavam com seu canudo. O personagem-narrador Cubas não poderia passar sem esta experiência tão comum à sua classe social: o diploma. No capítulo 20, o narrador-defunto demonstra toda sua insatisfação com o fato de ter que estudar em Coimbra, a fim de cumprir uma vontade de seu pai:

Tinha eu conquistado em Coimbra uma grande nomeada de folião, era um acadêmico estroina, superficial, tumultuário e petulante, dado às aventuras, fazendo romantismo prático e liberalismo teórico, vivendo na pura fé dos olhos pretos e das constituições sociais (ASSIS, 1997, p. 56).

Cubas descreve uma universidade cansativa e um estudante formado mediocremente, em festas e comemorações fora da sala de aula. Mesmo assim, cumpria seu papel social de preparar-se para o trabalho imaterial. Para ele, tanto a universidade quanto o diploma eram medíocres, pois atestava no pergaminho um conhecimento científico que ele não detinha, já que não tinha o menor interesse por isso. $\mathrm{O}$ diploma, muitas vezes, é também um componente do discurso do não trabalho, do antitrabalho e da "sede de nomeada", no sentido de resguardar o homem do trabalho material, aquele que suja as mãos, que traz fadiga. Machado reconstitui esse discurso por meio de uma crítica direta à universidade em contraste com o conhecimento tácito, adquirido no cotidiano, entre as pessoas comuns. Assim, contrapõe duas verdades:

Para lhes dizer a verdade toda, eu refletia as opiniões de um cabeleireiro, que achei em Módena, e que se distinguia por não as ter absolutamente. Era a flor dos cabeleireiros; por mais demorada que fosse a operação do toucado, não enfadava nunca; ele intercalava as penteadelas com muitos motes e pulhas, cheios de um pico, de um sabor [...] Não tinha outra filosofia. Nem eu. Não digo que a Universidade me não tivesse ensinado alguma; mas eu decorei-lhe só as fórmulas, o vocabulário, o esqueleto. Tratei-a como tratei o latim: embolsei três versos de Virgílio, dois de Horácio, uma dúzia de locuções morais e políticas, para as despesas da conversação. Tratei-os como tratei a História e a Jurisprudência. Colhi de todas as coisas a fraseologia, a casca, a ornamentação [...] (ASSIS, 1997, p. 62). 
O papel da universidade estava voltado para a ilustração superficial e não para a profissionalização, por isso não era muito pragmática, conforme a tradição portuguesa e brasileira do século XIX. Ter um curso superior, que tratasse das leis, das ciências biológicas, dava prestígio, já que era trabalho imaterial e permitia a quem o alcançasse fugir do trabalho material, associado à escravidão e, por conseguinte, à inferioridade. A atitude de Brás Cubas em relação à universidade era do mais absoluto descaso, porque ele sabia que o que ele aprendia ali era apenas para reforçar sua condição de classe privilegiada. Sua expectativa em relação à vida era outra, e os estudos eram mais um capricho de classe e de família. A elite representada, como já destacado, não é a industriosa e tecnológica, proeminente na Inglaterra da mesma época, em que a ciência era já um saber aplicado à tecnologia, no sentido de dar propulsão ao advento da maquinaria para a Revolução Industrial, já implantada e se fortalecendo desde o século XVIII.

Ligado ao discurso da glória não resultante do trabalho está o discurso da conquista de uma posição social de poder, por meio da aquisição de um diploma e de um cargo político, que é um trabalho imaterial. E o pai de Brás Cubas já tinha estabelecido esse norte para a vida do filho, quando esse retornou dos estudos universitários em Coimbra: “- Tu; é um homem notável, faz hoje as vezes de Imperador [referindo-se ao Príncipe Regen- te]. Demais trago comigo uma ideia, um projeto, ou [...] sim, digo-te tudo; trago dois projetos, um lugar de deputado e um casamento" (ASSIS, 1997, p. 65). Nesse universo discursivo, era imprescindível a carreira política, por vinte e tantas razões, segundo o pai de Cubas.

Então, surge-lhe a candidatura a deputado, refletindo a "sede de nomeada" do pai, que não aceita ter gasto fortuna na formação estrangeira do filho, para não ter um retorno equivalente. Ele quer brilhar por meio do filho: "[...] é preciso continuar o nosso nome, continuá-lo e ilustrá-lo ainda mais. [...] Teme a obscuridade, Brás; foge do que é ínfimo. Olha que os homens valem por diferentes modos, e que o mais seguro de todos é valer pela opinião dos outros homens" (ASSIS, 1997, p. 69). Silencia o fato de sua genealogia não ser de "boa estirpe" e diz que quer continuar a ilustrar seu nome. Esse enunciado é reiterado em outras passagens da obra, como para reforçar o discurso que recria a realidade da elite do século XIX: ter um nome e mantê-lo, ser alguém é muito importante para essa classe e, para isso, não precisa de trabalho. $\mathrm{O}$ valor do homem dessa classe social é dado não pelo trabalho ou pelo esforço, mas pelo galgar de degraus na escala do poder e, para isso, o trabalho imaterial cumpre seu papel.

Percebe-se um embate claro entre o discurso do trabalho implantado pelas elites liberais da época em oposição ao do não trabalho ou do antitrabalho, que consiste na realidade vigente para as 
elites improdutivas. Porém, também remete à alteridade tratada por Bakhtin e o Círculo, quando se nota que o eu de Brás Cubas não surgiu, enquanto não foi traduzido em intersubjetividade, por meio da opinião e do olhar do outro em sociedade. É o que o pai dele quer, que ele não só seja alguém, mas que seja visto como alguém pela sociedade.

Nota-se que, por todos os lados, o discurso da "sede de nomeada" está presente, como uma cultura entranhada no âmago da sociedade, desbancando qualquer outro discurso contrário. Enquanto Cubas parece-nos um vacilante, seu pai luta até a morte para vê-lo ascender socialmente. Seu pai sentiu-se tão envergonhado pelo filho não ter conseguido a candidatura a deputado, que morreu quatro meses depois de puro desgosto. Seus castelos desmoronaram-se, porque não lhe bastava a fortuna, queria ver seu filho galgando um posto qualquer de destaque na sociedade. Esquecia-se do antepassado tanoeiro e repetia reiteradamente: "Um Cubas!", para atrair para o seu presente o passado que ele queria lembrar e que está associado à figura do licenciado. Sua única alegria antes de morrer foi a visita de um ministro a seu leito de morte, confirmando a força do discurso do poder e do orgulho pela glória.

Brás Cubas não precisava trabalhar, pois tinha quem o sustentasse, mas o discurso que dominava na sociedade da época conduzia-o a várias tentativas de colocar-se dentro da ordem estabelecida para os homens. Ele estava determinado socialmente, por uma ordem que gritava para que ele galgasse um posto na sociedade, para que assumisse um cargo no alto escalão ou para que chefiasse alguém. Relacionar-se com o outro, conviver, estabelecer contato pouca importância tinha para Brás Cubas. Ele podia optar, mas ao mesmo tempo não tinha escolha, sua classe determinava sua ocupação ou possível colocação. Por isso, Cubas, após a morte de seu pai e a perda da candidatura a deputado, tem outro vislumbre: ser ministro.

- Por que não serei eu ministro? Esta ideia, rútila e grande, trajada ao bizarro, como diria o padre Bernardes, - esta ideia começou uma vertigem de cabriolas e eu deixei-me estar com os olhos nela, a achar-lhe graça. [...] - Por que não serás ministro, Cubas? Cubas, por que não serás ministro de Estado? (ASSIS, 1997, p. 107).

No entanto, essa é mais uma ideia vacilante que não se concretiza para esse homem já maduro e sem colocação na vida. Cubas é um errante profissional, que não precisa de dinheiro, porque é rico, mas que precisa de uma posição social de destaque. Então, surge nova oportunidade ao ser convidado por Lobo Neves, marido de sua amante e futuro presidente de uma província no Norte, para segui-los como secretário. “- Você é rico, continuou ele, não precisa de um magro ordenado; mas se quisesse obsequiar-me, ia de secretário comigo" (ASSIS, 1997, p. 136). Na voz de um homem bem-sucedido e ganancioso, Machado coloca o discurso de classe. Porém, mais uma vez, o destino ou a sorte ${ }^{12}$ impede-o de assumir esse cargo que, 
além de outras possibilidades, dar-lhe-ia a satisfação da "sede de nomeada".

Além do mito discursivo da honra e da dignidade pelo trabalho, seja ele material ou imaterial, está a "sede de nomeada", que ultrapassa todos os limites da ética. Prevalece, então, o embate entre os discursos de glória a partir do sonho da nomeação por porte de um diploma e a fadada mediocridade muito criticada, mas não realmente enfrentada.

Mesmo a sociedade liberal burguesa valorizando o trabalho como um dos formadores do destino histórico do homem, Cubas não dá a mínima importância a ele, não trabalha e não se submete. Para o jovem Brás, pouco importa se o trabalho é dignificante ou benéfico, ele o ignora completamente. Desconhece esses aspectos, embora os utilize em seus enunciados com Quincas Borba, o que veremos mais adiante.

Nesse ponto, ele desvincula trabalho a profissão. Trabalhar ele nunca trabalhou, mas tinha uma profissão pela qual queria ser reconhecido e falava sobre ela, impondo-lhe valor. Machado estabelece essa dualidade entre os que trabalham e os que não trabalham, mas têm uma profissão, na sociedade e na cultura do trabalho. Para Cubas, o que importa e do que ele precisa é de glória. E isso só viria com uma colocação política ou com uma descoberta como a do emplasto.

Na prática dessa enunciação, o homem é cobrado socialmente a ter determinadas posturas condizentes com o discurso. Quando o seu meio, através da opinião alheia, não lhe faz nenhuma cobrança, ele mesmo se cobra. No caso de Brás Cubas, a cobrança fustiga-o, quando, ao completar quarenta anos e perder seu filho esperado por Virgília, tem uma crise de consciência e dá-se conta de que: “[...] não era nada, nem simples eleitor de paróquia. Urgia fazer alguma coisa, ainda por amor de Virgília, que havia de ufanar-se quando visse luzir o meu nome [...]" (ASSIS, 1997, p. 160). Contudo, essa atitude é apenas um drama de consciência passageiro, gerado pela crise da idade, porque não tem qualquer efeito prático sobre sua vida: vê-se com seus "quarenta e tantos anos, tão vadios e tão vazios" (ASSIS, 1997, p. 176). Perceba-se que "luzir o meu nome", em sua fala, só confirma que qualquer atividade laboral só se justifica para ele no sentido narcísico, em que ele será valorizado em detrimento do produto que realize e que possa beneficiar a sociedade. A ideia de trabalho social e produtivo para o coletivo está ausente.

Cubas sente a perda de uma pretendente ao casamento, Eulália Damasceno de Brito, mas, fazendo jus ao anti-herói que é, volta à sede de luzir e ao namoro com os aplausos. Ele quer brilhar, sentir-se importante. Gostava de gente e não queria ficar só. Finalmente, aos quarenta e tantos anos, dois anos depois da morte de sua noiva, Cubas vê-se na câmara dos deputados, ao lado de Lobo Neves, sem remorsos, realizando um desejo antigo, desejando galgar a posição de ministro de Estado. A "sede de 
nomeada", como um discurso de longa duração, persiste ao longo da trajetória final de Brás Cubas. Aos cinquenta anos, o narrador-defunto decide tomar governo de sua vida. Passa, então, a intervir nas discussões da Câmara, onde anteriormente fazia as vezes de um demagogo. No seu questionamento mesquinho ao ministro sobre o tamanho da barretina, da guarda nacional, faz um discurso eloquente, elogiado por todos, mas irrelevante do ponto de vista político. Relevante colocar que suas posições eram todas elogiadas por Quincas Borba e que isso era fundamental para o personagem defunto, que não tinha amigos e precisava de elogios. Entretanto, Cubas também não se faz ministro de Estado, e diz isso no título de um capítulo, no qual não escreve absolutamente nada, apenas pontilhados:

] (ASSIS, 1997, p. 200). É a representação do completo vazio em que se encontra o personagem.

Contudo, a história é longa e permanente como o discurso sobre o trabalho, e Cubas perdeu a cadeira da câmara dos deputados, finalizando sua carreira política, o que o deixou consternado. Ele tinha quase tudo, mas faltava-lhe a cadeira política da qual sentia saudades: a "sede de nomeada". Isso era o que dava sentido a sua vida: ser ouvido e apreciado, luzir. Ele tinha simpatia pelas palavras que bajulam, elogiam.

Outras ideias surgem no sentido de suprir e alimentar a "sede de nomeada", o desejo de luzir, como a proposta de fundar um jornal para "desmanchar toda essa igrejinha”, referindo-se aos deputados. Cubas estava convencido a publicar em seu próprio jornal, na perspectiva de ter algo para fazer, algo que fosse útil e que preenchesse seus dias vazios. Mas, infelizmente, seus planos não vingaram e, seis meses depois de fundado, o jornal teve uma morte clandestina.

Assim, o vacilante Brás Cubas volta à estaca zero, comprovando que nada 0 move realmente, não necessitando lutar por nada. O último movimento de Brás Cubas, antes de sua morte, é em direção à fase mais brilhante da sua vida, quando, na solidão, filia-se a uma Ordem Terceira, na qual exerce alguns cargos e faz alguns serviços de caridade aos pobres e aos enfermos. Entretanto, ficou nesse serviço apenas três ou quatro anos: "No fim de alguns anos, três ou quatro, estava enfarado do ofício, e deixei-o, não sem um donativo importante, que me deu direito ao retrato na sacristia" (ASSIS, 1997, p. 218). Brás Cubas está sempre a confirmar seu gosto pelo prestígio, quando faz donativos à Ordem Terceira apenas para livrar-se dos trabalhos voluntários e ter seu retrato na sacristia, como uma forma de bajulação.

A busca por glória está em todas as atitudes de Cubas, mas não se concretiza e ele, apesar de não transparecer, faz pouco caso de cada uma das tentativas. É apenas mais uma forma de ele alcançar algum prestígio social. 


\section{Trabalho e antitrabalho na voz de Quincas Borba}

Quincas Borba é o personagem que aparece em duas obras machadianas diferentes. Na obra homônima, Quincas Borba morre deixando sua herança para seu amigo Rubião, personagem principal do romance, sob a condição de esse cuidar do seu cão, que também se chamava Quincas Borba. Em Memórias póstumas, Quincas Borba é um personagem secundário, que aparece algumas vezes mais ao final da obra e que tem um papel fundamental na forma como Brás Cubas passa a encarar sua vida quando está se aproximando do fim.

Homem inteligente e de família rica, Quincas Borba havia sido companheiro de colégio de Brás Cubas, com o qual se reencontrara muitos anos depois em condições muito diferentes das que conviviam na infância:

[...] Uma vida de misérias, de atribulações e de lutas. Lembra-se das nossas festas, em que eu figurava de rei? Que trambolhão! Acabo mendigo... E alçando a mão direita e os ombros, com um ar de indiferença, parecia resignado aos golpes da fortuna, e não sei até se contente. Talvez contente. Com certeza, impassível. Não havia nele a resignação cristã, nem a conformidade filosófica. Parece que a miséria lhe calejara a alma, a ponto de lhe tirar a sensação de lama. Arrastava os andrajos, como outrora a púrpura: com certa graça indolente (ASSIS, 1997, p. 108).

Sua trajetória de vida era bastante peculiar, pois tinha sido abastado na infância e, na vida adulta, experimentara a mendicância, por questões familiares. Nessas condições, ele via o trabalho com desdém. Para Quincas, trabalhar não resultava em nada: não lhe traria dignidade, reconhecimento ou realização pessoal. No primeiro encontro entre os personagens, por exemplo, Brás Cubas promete-lhe arranjar-lhe algo e ele responde: "[...] Eu nada peço, a não ser dinheiro; dinheiro sim, porque é necessário comer, e as casas de pasto não fiam. Nem as quitandeiras. Uma coisa de nada, uns dois vinténs de angu, nem isso fiam as malditas quitandeiras [...]" (ASSIS, 1997, p. 108-109). O que Quincas almejava era ter dinheiro para comer. Ainda nesse encontro, Cubas deu-lhe uma nota de cinco mil-réis e lhe disse: "- Pois está em suas mãos ver outras muitas, disse eu. - Sim? Acudiu ele, dando um bote para mim. - Trabalhando, concluí eu" (ASSIS, 1997, p. 109).

Machado de Assis utiliza sua tradicional ironia para, por meio de seu narrador-defunto-onisciente, que também é um personagem que está sendo narrado, trazer à tona a cultura do trabalho da sociedade liberal burguesa da época. A ênfase dada nas palavras, inclusive pelo fechamento da frase com um verbo no gerúndio, indicando continuidade, reforça o discurso latente do trabalho, mas que está desestabilizado e a ponto de emergir. Então, o discurso do trabalho surge como um conselho, mas também como uma ordem ou um chamamento, para que o personagem se junte ao exército 
de trabalhadores, que mesmo não sendo assalariados, conseguem o seu sustento.

Quincas nega-se e oferece-lhe um bote, que é um símbolo de esmola; em contrapartida, Cubas dá-lhe a alternativa do trabalho. Essa negação significa a escolha social por um modo de vida mais fácil: "Fez um gesto de desdém; calou-se alguns instantes; depois disse-me positivamente que não queria trabalhar" (ASSIS, 1997, p. 109).

Como resposta a essa colocação de Cubas, Quincas dá-lhe um abraço, durante o qual, ironicamente, furta-lhe $o$ relógio, que tempos depois lhe devolve com uma carta, expondo sua mudança de status: no retorno, já não era mais um morador de rua no degrau da escada de São Francisco, vestia-se como um homem de valor, "um desembargador sem beca, um general sem farda, um negociante sem deficit" (ASSIS, 1997, p. 170). Não surge no personagem Quincas qualquer culpa moral pelo furto do relógio. $\mathrm{O}$ roubo, o saque e o apropriar-se do alheio, atitudes muitas vezes comuns na sociedade, podem estar representados nessa atitude do personagem, sendo também vinculados às classes abastadas que não trabalham, mas usurpam o produto do labor alheio. Na sociedade oitocentista, como referido, a elite vivia às expensas, sobremodo, do trabalho escravo. Quincas elevou-se de mendigo a herdeiro, sem ter que fazer qualquer esforço físico para isso.

A atitude de Brás Cubas em relação a Quincas Borba reforça o discurso la- fargueano de que o trabalho é uma "estranha loucura", criada por aqueles que têm dinheiro, para deter as atitudes de resistência daqueles que nada têm, contendo seus desejos. O narrador-defunto é uma voz enaltecedora do trabalho dos outros, mas, como já sabemos, não tem qualquer amor ao próprio trabalho.

A forte cultura do trabalho, transposta da Europa e dos países de política econômica liberal burguesa para o Brasil, é reforçada pela ideia fixa que ficou na cabeça de Brás Cubas, após o encontro com seu velho amigo Quincas. Ele queria regenerá-lo para o trabalho: "A necessidade de o regenerar, de o trazer ao trabalho e ao respeito de sua pessoa enchia-me o coração; eu começava a sentir um bem-estar, uma elevação, uma admiração de mim próprio [...]" (ASSIS, 1997, p. 111). Essa atitude constitui um discurso elitista sobre o trabalho: aqueles que trabalham pouco, e têm muito, costumam afirmar que os que não têm nada é porque não trabalham. Evitam admitir que essa possa ser, muitas vezes, uma atitude de resistência, ao perceberem a impossibilidade de ascensão, pela via tradicional do trabalho, ou simplesmente uma consequência da imersão na cultura do país onde vivem, que não prestigia o trabalho.

Borba conta a seu amigo que mudou de status dado a um trabalho imaterial de estudo e de pesquisa de um novo sistema de filosofia, intitulado Humanitismo, de Humanitas, inovador e transformador, do seu ponto de vista. Por esse objeti- 
vo, Quincas tinha transformado sua vida $\mathrm{e}$, segundo ele, encontrado a verdade e a felicidade. Machado, com essa narrativa, satiriza o trabalho imaterial dos filósofos brasileiros. O Humanitismo enquanto filosofia é ironizado e ridicularizado, como trabalho imaterial. O narrador-defunto prefere acreditar que Quincas havia herdado alguma fortuna dos parentes de Minas e que com isso lhe havia sido devolvida a dignidade. Em outras palavras, a voz que emerge nesse discurso diz que o trabalho, ainda que imaterial, não outorga nenhum benefício monetário. Apenas por meio de herança, o homem pode transpor a barreira da pobreza. No final, Cubas acaba admitindo que Quincas tinha herdado alguns pares de contos de réis de um velho tio de Barbacena. O trabalho não lhe havia restituído à condição digna.

Em outras palavras, o sentido da vida não estava necessariamente no trabalho, mas na atividade de luta para conseguir uma posição social de prestígio. $\mathrm{O}$ próprio Quincas comprova sua "sede de nomeada", ao reivindicar que fosse feita uma declaração de que alguns princípios do texto publicado na edição do jornal elaborado por Cubas foram retirados do seu livro sobre a filosofia Humanitismo. Também se percebe que a filosofia que criara passa a ter certo prestígio, porque emana de alguém pertencente às elites. Aqui, o discurso só é valorizado porque quem o profere está vinculado às classes que podem exercer o labor imaterial. Novamente, o determinismo de classe sobre a divisão entre trabalho material e imaterial.

Quincas Borba, assim como Brás Cubas, é a representação da negação do discurso do trabalho como parte da cultura brasileira.

\section{Considerações finais}

As práticas sociais relativas ao trabalho no século XIX estão representadas nos discursos da literatura machadiana em vários enunciados. Neste artigo, buscamos apresentar a forma como Machado de Assis expõe sua visão de mundo sobre a cultura do trabalho, a partir dos personagens Brás Cubas e Quincas Borba, do romance Memórias póstumas, e percebemos que, diferentemente do discurso sobre o trabalho como forma de alcançar a dignidade, o reconhecimento e a realização pessoal, o que emerge é a enunciação da necessidade humana de prestígio, de ser ovacionado pelos grandes da sociedade, ao galgar uma posição de destaque político, econômico ou social, representada algumas vezes pelo trabalho imaterial ou pelo não trabalho. $\mathrm{Na}$ prática, a dignificação pelo trabalho não ocorre, pois os discursos que o nomeiam positivamente são a todo o momento interditados. Em Memórias póstumas, a elite improdutiva foge do trabalho.

$\mathrm{Na}$ sociedade burguesa do Rio de Janeiro do século XIX, estilizada por Machado, não se aplicava a condição do homem significar-se pelo trabalho, pois a prática era o filho de família rica ir 
estudar em Coimbra e voltar com um diploma, com a pretensão de seguir uma carreira pública e diferenciar-se dos demais. O objetivo era alcançar a glória na sociedade, a sobrevivência e ascensão do nome da família, uma herança portuguesa, nas palavras de Sérgio Buarque de Holanda.

Assim, a análise dialógica do discurso sobre o trabalho levou-nos a considerar, finalmente, que a elite burguesa do Brasil oitocentista, no Rio de Janeiro, fugia ao trabalho, pois não precisava dele para sobreviver. Outros trabalhavam por ela. Embora a cultura do trabalho seja um discurso vociferante, na obra, o que predomina na análise dos dois personagens é o discurso do não trabalho ou do antitrabalho, já que o trabalho estava a cargo do escravo. Nessa fuga ao trabalho material, surge uma visão negativa e depreciatória sobre ele.

Ambos os personagens, Borba e Cubas, morrem sem alcançar glória alguma, nem pelo trabalho nem pelo não trabalho. Borba, na sua semidemência, queima o manuscrito da sua teoria $\mathrm{Hu}$ manitismo, que era sua esperança de glória. Cubas, sem concluir a invenção do Emplasto Brás Cubas, sem tornar-se ministro ou califa, morre sem glória, mas conclui que pelo menos teve a sorte de não comprar o pão com o suor do seu rosto, que é o ideal de boa parte de sua classe social.
The non-work culture as a vociferous speech in the voices of Brás Cubas and Quincas Borba

\begin{abstract}
This paper analyzes the discursive constructions on the work culture, in the work Posthumous Memories of Brás Cubas (1881), by Machado de Assis, making a discursive cross section by voices brought by Brás Cubas and Quincas Borba characters. Considering that the cultural universe created by the novelistic author reflects and refracts its time, and there is not how to push away culture from language's dialogical orientation, since this relationship presupposes otherness and discourse, we make a dialogical analysis, based on the theories of Bakhtin and the Circle. The voices of Machado's enunciation reframe the long duration discourse of dignity, recognition and personal fulfillment originated from material or immaterial work to non-work or anti-work by the dominant classes who are "named headquarters", through the acquisition of a diploma or political office. We conclude that, to the nineteenth-century Brazilian elites, what prevailed was the nonwork culture.
\end{abstract}

Keywords: Culture. Work. Speech. Cubas and Borba. Machado de Assis. 


\section{Notas}

1 "Sede de nomeada" é a expressão cunhada por Machado de Assis para representar o desejo de glória dos homens. Em algumas obras, o sentimento aparece como característico dos personagens. Na obra Quincas Borba, por exemplo, para referir-se ao momento em que o Rio de Janeiro recebeu a notícia, publicada no jornal Atalaia, do salvamento de uma criança quase atropelada por um cupê, realizado pelo personagem Rubião, o narrador descreve atitudes e pensamentos que personificam esse sentimento. Rubião, a princípio, aborrece-se com Camacho, o dono do jornal: "[...] que diacho de ideia aquela de imprimir um fato particular, contado em confiança”. Entretanto, à medida que os elogios se multiplicam, passa a saborear a publicidade, a ponto de o impulso inicial de pedir satisfações ao dono converter-se em agradecimento e o desejo de anonimato, em "sede de nomeada": "Rubião foi agradecer a notícia ao Camacho, não sem alguma censura pelo abuso de confiança, mas uma censura mole ao canto da boca. Dali fora comprar uns tantos exemplares da folha para os amigos de Barbacena. Nenhuma outra transcreveu a notícia: ele, a conselho de Freitas, fê-la reimprimir nos 'a pedidos' do Jornal do Comércio interlinhada" (ASSIS, 1988, p. 92-94). Da mesma forma, em Memórias póstumas, a expressão é mencionada pelo narrador-defunto Brás Cubas para nomear o desejo de obter reconhecimento social por meio de nomeações e cargos públicos: "Para que negá-lo? Eu tinha a paixão do arruído, do cartaz, do foguete de lágrimas. Talvez os modestos me arguam desse delito; fio, porém, que esse talento me hão de reconhecer os hábeis. Assim, a minha ideia trazia duas faces, como as medalhas, uma virada para o público, outra para mim. De um lado, filantropia e lucro; do outro lado, sede de nomeada. Digamos: - amor da glória" (ASSIS, 1997, p. 15).

2 Segundo Beth Brait, estudiosa de Bakhtin e do Círculo, a expressão análise dialógica do discurso surgiu na década de 1980 e foi criada pelos estudiosos da obra do filósofo russo, no Brasil, como uma forma de transitar pelas diferentes noções presentes na sua obra, utilizando-se de diferentes corpora, buscando encontrar sujeitos diversos e em diálogo com outros sujeitos e cronotopos $\mathrm{Na}$ totalidade da obra de Bakhtin e do Círculo, não existe essa expressão. (disponível em: <https://www.youtube.com/watch? $v=Y 11 D 4 j M U 1 N c>$ ). Utiliza-se o termo ADD a fim de diferenciar-se de outro campo teórico que constitui a análise do discurso $(\mathrm{AD})$, advindo, sobretudo, de inspiração de teóricos franceses. Brait (2016) esclarece a necessidade de diferenciar os termos, visto que, embora haja pontos de contato, também, há especificidades concernentes às ideias dos pensadores que integraram o Círculo russo.

3 O poeta oral grego Hesíodo escreve sobre a dignidade do trabalho material, reforçando uma cultura positiva sobre o labor, mesmo em uma sociedade escravista como era a grega. Esse discurso é altamente significativo, mas tem pouca repercussão e circulação nos estudos modernos sobre o trabalho, que datam do século XIX e XX.

4 Na peça Prometeu acorrentado, do dramaturgo grego Ésquilo, é sobejamente conhecida a temática do labor humano que liberta os homens do jugo dos deuses. Prometeu confere aos homens técnica e trabalho, o que os liberta da hierarquia a que eram submetidos.

5 A Bíblia é um conjunto discursivo bastante diverso e apresenta inúmeras vozes sociais sobre o trabalho material e imaterial. Sabe-se que a Literatura Brasileira, mediante vários escritores, mantém uma dialogia em consenso e dissenso com esses discursos, pois fazem parte de uma tradição enunciativa ocidental. Machado, em sua vasta obra, apresenta esse diálogo de modo bastante concreto. Não cabe aqui trazer toda essa interdiscursividade, mas há que se mencionar e destacá-la, quando for procedente na análise das vozes sobre trabalho.

6 Paul Lafargue (1842-1911): jornalista socialista franco-cubano, escritor e ativista político, que escreveu a obra $O$ direito à preguiça. Casou-se com a segunda filha de Karl Marx, de nome Laura.

7 No livro de Eclesiastes 2:11, Salomão, depois de enumerar vários prazeres desejados e alcançados pelo homem, diz: "Então olhei eu para todas as obras, que as minhas mãos haviam feito, como também para o trabalho que eu aplicara em fazê-las; e eis que tudo era vaidade e desejo vão, e proveito nenhum havia debaixo do sol".

8 Tanoeiro é o profissional que fabrica ou conserta tonéis ou pipas. Esses tonéis, dentre outras funções mais admiráveis, como conter água, tinham que transportar excrementos das 
casas para serem jogados ao mar, por meio dos Tigres (ou tigrada), que eram os escravos que os carregavam.

9 Quem possuía título acadêmico à época, em Portugal chamava-se licenciado.

10 Machado de Assis organiza a sua visão de mundo (axiológica) a partir das vozes dos personagens. O romance é sempre um discurso indireto, segundo Bakhtin e o Círculo. O autor "fala" por intermédio das vozes que organiza na obra literária, sendo ele sempre o organizador discursivo.

11 Excedente de visão é o conceito, elaborado por Bakhtin, que designa a capacidade privilegiada de ver o outro, além de si, possível apenas porque se está de fora, de outro lugar, único em relação ao que se está narrando ou retratando.

12 Lobo Neves, marido de Virgília, desiste da nomeação de presidente de província, porque era supersticioso e o decreto veio sob o número 13. Assim, Cubas também perdeu a oportunidade de tornar-se secretário.

\section{Referências}

ASSIS, M. M. Memórias póstumas de Brás Cubas. Rio de Janeiro: Ediouro, 1997.

Quincas Borba. Rio de Janeiro: Tecnoprint/Ediouro, 1988.

BAKHTIN, M. M. O problema do herói na atividade estética. In: BAKHTIN, M. M. Estética da criação verbal. Trad. Maria Ermantina G. G. Pereira. São Paulo: Martins Fontes, 2000.

Questões de literatura e de estética: a teoria do romance. 6. ed. Trad. Aurora Fornoni Bernardini, José Pereira Júnior, Augusto Goés Júnior, Helena Spryndis Nazário e Homero Freitas de Andrade. São Paulo: Hucitec, 2010.

BRAIT, B. Bakhtin: outros conceitos-chave, 2. ed., 2. reimpr. São Paulo: Contexto, 2016.

CANDIDO, A. Literatura e sociedade. Rio de Janeiro: Ouro sobre Azul, 2006.
DAMATTA, R. Explorações: ensaios de sociologia interpretativa. São Paulo: Rocco, 1986.

O que faz o brasil, Brasil? Rio de Janeiro: Rocco, 1993.

ÉSQUILO. Prometeu acorrentado. Trad. Miroel Silveira e Juliana Silveira Gonçalves. São Paulo: Abril Cultural; Editor Victor Civita, 1980.

GEERZ, C. A interpretação das culturas. Rio de Janeiro: Guanabara, 2014.

HESÍODO. Os trabalhos e os dias. 3. ed. São Paulo: Iluminuras, 1996. (Introdução, tradução e comentários de Mary C. N. Lafer).

HOLANDA, S. B. de. Raízes do Brasil. 26. ed. São Paulo: Companhia das Letras, 2009.

LAFARGUE, P. O direito à preguiça e outros textos. Trad. Maria Flor Marques Simões. Lisboa: Editorial Estampa, 1977.

MARX, K.; ENGELS, F. O manifesto comunista. Trad. Maria Lucia Como. São Paulo: Paz e Terra, 1997.

SCHWARZ, R. Ao vencedor as batatas. Forma literária e processo social nos inícios do romance brasileiro. 6. ed. São Paulo: Duas Cidades; Editora 34, 2012. 